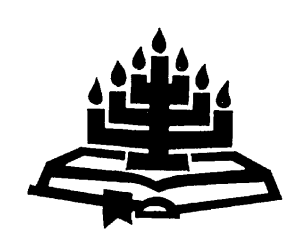

\title{
'n Reformatoriese samelewingsfilosofie: 'n sistematiese uiteensetting, kritiese evaluering en praktiese toepassing
}

\author{
B.J. van der Walt \\ Skool vir Filosofie \\ Noordwes-Universiteit \\ Potchefstroomkampus \\ POTCHEFSTROOM
}

E-pos: hannah@intekom.co.za

\section{Abstract

\begin{abstract}
A Reformational social philosophy: systematic exposition, critical evaluation and practical application
\end{abstract}

The problem to be discussed in this contribution is that many Christians, churches and theologians are often guided by no or merely a very vague (worldviewish) perspective on social life. Sometimes they are even inspired by unbiblical methods (e.g. earlier Marxism and contemporary neocapitalism or postmodernism) in their social analysis. This may be an important contributing factor for the sad fact that Christians often have very little impact on the broader social domain (the "public square") outside their personal and church life. Therefore this article looks at a possible solution in the following steps: It begins with a comparison between the three basic philosophies of society, viz. individualism, collectivism and pluralism. Then it provides a systematic exposition of a Christian-reformational, pluralistic social philosophy as a possible candidate. To indicate that a reformational social philosophy neither wants to pretend, nor wants to be regarded as a static dogma or ideology, the next section reviews some points of critique voiced by its sympathetic proponents. The fourth section investigates how this social view may inspire social change. Following the preceding, more theoretical exploration, it discusses possibilities for its practical application. In this way a complete answer (both theoretical and practical) is given to the urgent problem indicated at the beginning, viz. the little influence of Christians on the so-called public sphere. 


\section{Opsomming}

\section{'n Reformatoriese samelewingsfilosofie: 'n sistematiese uiteensetting, kritiese evaluering en praktiese toepassing}

Die probleem wat hier onder die loep geneem word, is dat Christene, kerke en teoloë dikwels deur geen of 'n baie vae lewensbeskoulike perspektief op die sosiale lewe gelei word. Soms word selfs van nie-Bybelse metodes (soos vroeër die Marxisme en deesdae die neokapitalisme of postmodernisme) gebruik gemaak om die samelewing te analiseer. Dit kan 'n belangrike bydraende rede wees vir die ongelukkige feit dat Christene dikwels weinig invloed op die breë samelewing (die sg. openbare terrein) buite hulle persoonlike en kerklike lewe het. Hierdie artikel ondersoek 'n moontlike oplossing deur die volgende stappe: Dit begin met 'n vergelyking tussen die drie basiese samelewingsfilosofieë, naamlik individualisme, kollektivisme en pluralisme. Dit gee daarna 'n sistematiese uiteensetting van 'n Christelik-reformatoriese pluralistiese samelewingsfilosofie as moontlike kandidaat. Om aan te dui dat hierdie samelewingsfilosofie nie 'n statiese dogma of ideologie wil wees of só beskou moet word nie, bevat die volgende afdeling 'n kort oorsig oor enkele kritiekpunte wat deur simpatieke voorstanders geopper word. Die vierde afdeling gee 'n aanduiding van hoe hierdie samelewingsvisie tot samelewingsverandering kan lei. Na die voorafgaande meer teoretiese verkenning, vestig dit die aandag op die praktiese toepasbaarheid. Op hierdie wyse word 'n volledige antwoord (teoreties en prakties) gebied op die belangrike probleem wat aan die begin gestel is, naamlik die geringe impak van Christene op die sogenaamde openbare lewe.

\section{Inleiding: probleem, aanpak, opset en terminologie}

\subsection{Probleem}

Die probleem wat hier ondersoek word, is dat Christene en Christelike teoloë dikwels oor geen of 'n baie elementêre, onomlynde samelewingsbeskouing beskik, wat as (teoretiese) leidraad kan dien om (prakties) in die breë samelewing buite hulle kerke betrokke te wees. Ander Christene werk soms wel vanuit 'n sistematiese visie, maar omdat hulle van sekulêre metodes gebruik maak (bv. in die verlede die Marxisme en vandag samelewingsanalises deur die neokapitalisme of die postmodernisme geïnspireer) kan dit moeilik as integraal-Christelike samelewingsfilosofieë kwalifiseer. 


\subsection{Aanpak}

Omdat die Reformatoriese samelewingsfilosofie redelik onbekend is in kerklike en teologiese kringe (veral in Suid-Afrika), en ook om dit vir 'n so groot moontlike leserspubliek toeganklik te maak, sal by hierdie uiteensetting onnodige tegniese/ingewikkeldheid vermy word.

\subsection{Opset}

Nadat in 'n vorige artikel (vgl. Van der Walt, 2008) verantwoording gedoen is oor die Bybelse begronding van die Reformatoriese samelewingsfilosofie asook kortliks ingegaan is op die ontwikkeling daarvan in die loop van die geskiedenis, word dit hier vollediger sistematies uiteengesit. Dit word gevolg deur enkele vrae oor sekere aspekte daarvan. Ten slotte word aangedui hoe hierdie samelewingsvisie met vrug op verskillende maniere prakties toegepas kan word.

\subsection{Terminologie}

Hierdie laaste inleidende opmerking verduidelik die term Reformatories, aangesien dit verkeerd verstaan mag word. Dit word hier nie in 'n kerklike sin verstaan as verwysend na 'n sekere groep kerke (die Reformatoriese of gereformeerde kerke) nie. Dit word ook nie in konfessionele sin bedoel (met die konnotasie van 'n sekere aantal belydenisskrifte uit die tyd van die sestiende-eeuse Reformasie) nie. Hierdie twee betekenisse is nie heeltemal uitgesluit nie. Die derde betekenis waarin dit egter hier gebruik word, dui op 'n Reformatoriese of transformasionele lewensvisie.

Accordingly, it stands for a cultural perspective that calls for the renewal of peoples and the reformation of society in keeping with biblical principles for our life together in God's world - a vision that Reformed Christians share with many Christians from other traditions. (Spykman et al., 1988:xiii-xiv.)

Die unieke van 'n Reformatoriese samelewingsteorie kom des te duideliker uit die verf wanneer dit teenoor gangbare samelewingsteorieë gestel word. Daarom word ter inleiding eers 'n vergelyking tussen drie hoofstandpunte gemaak.

\section{Die drie basiese samelewingsfilosofieë}

Volgens die meeste skrywers (vgl. byvoorbeeld McCarthy et al., 1981:13-40; Marshall, 1994 en Skillen \& McCarthy, 1991:2 e.v.) be- 
staan daar, afgesien van kleinere variasies en vermengings tussen hulle, net drie basiese samelewingsfilosofieë. Hulle is eerstens die individualistiese, liberalistiese of atomistiese, tweedens die kollektivistiese, holistiese of organistiese (wat bv. die sosialisme, kommunisme en kommunalisme insluit) en derdens die pluralistiese. Grondliggend aan hierdie uiteenlopende samelewingsvisies moet verskillende mensbeskouings onderskei word. (Vir 'n uiteensetting van die antropologiese grondslae van die liberalisme en die sosialisme, vgl. byvoorbeeld Klapwijk, 1995a en Van der Walt, 2002:233-237.)

\section{1 'n Kort tipering van die liberalisme en kollektivisme}

Die hooftrekke van hierdie twee samelewingsvisies kan in die volgende punte saamgevat word.

\subsubsection{Individualisme}

- Die individu is die mees reële werklikheid, die fundamentele bousteen van die samelewing en die setel van gesag.

- Sosiale instellings of samelewingsverbande is bloot kolleksies van selfbepalende individue, wat saamkom om 'n gemeenskaplike doel te bereik.

- Samelewingsverbande dra 'n kontraktuele karakter en bestaan alleen solank die individuele lede dit goed vind en hulle individuele regte nie geskend word nie.

- Samelewingsverbande is dus menslike uitvindings, het geen transendente (goddelike) oorsprong nie en word ook volgens menslike goeddunke ingerig, omdat daar ook nie van goddelike norme sprake kan wees nie.

'n Voorbeeld ter illustrasie: Die staat ontvang sy gesag van die individuele onderdane wat (deur die verkose owerheid) kontraktueel verbonde is om hulle onvervreembare (individuele) regte te beskerm. Word individuele vryheid bedreig, mag die regering afgedank word.

\subsubsection{Kollektivisme}

Die hooftrekke van die kollektivisme, kommunalisme of sosialisme is die volgende:

- Die kollektiwiteit (stam, politieke party, volk of staat) is die primêre werklikheid en dus die setel van gesag. 
- Die individu vind sy betekenis alleen binne hierdie geheel, wat ook meer is as die som van die dele. (Presies die omgekeerde as die individualisme.)

- Alle menslike verbande is bloot middele om die doel van die groter geheel te bereik. Die groot geheel, en nie die individuele lede nie, besit ook regte.

- Ook hier geld (net soos by die individualisme) dat aan die samelewing deur die mens (die groep) volgens eie goeddunke gestalte gegee word.

'n Voorbeeld ter illustrasie: Die staat is 'n allesomvattende, absoluut soewereine samelewingsverband wat individue en ander samelewingsverbande (gesin, skool, bedryf, ens.) vir sy (politieke) doel organiseer. Hy kan sekere magte en regte aan individue en groepe delegeer, maar dit behoort nie inherent aan hulle nie.

\subsection{Kritiek op die twee modelle}

Die volgende kommentaar kan vanuit 'n pluralistiese vertrekpunt gelewer word:

\subsubsection{Die individualisme}

Die individualisme bevat 'n waarheidsmoment, 'n korrekte insig, want die enkeling is belangrik. Dit word egter verkeerd uitgewerk, want die individu mag nie oorbeklemtoon word nie, individuele regte is nie absoluut nie, mense is ook nie hulle eie wetgewers (outonoom) nie, en die inherente, sosiale aard van die mens mag nie misken word nie.

Individualiste kan nie hulle standpunt konsekwent handhaaf nie. Die mens het sosiale instellings nodig om in al sy behoeftes te voorsien. Hoewel hulle die staat dus bloot as 'n kontrak beskou, word dit as gevolg van nuttigheidsoorwegings geleidelik die mees reële instelling in die samelewing en bedreig dit die vryheid van die individu. Selfs 'n demokrasie kan totalitêr word.

\subsubsection{Die kollektivisme}

Die waarheidsmoment in sosialisme of kommunalisme (albei kollektivisties) is dat menslike gemeenskappe en eenheid inderdaad belangrik is. Die dwaling is dat geen samelewingsverband 'n megastruktuur en dié standaard vir die res van die samelewing mag wees nie. Op hierdie wyse word 'n soteriologiese, verlossende waarde daaraan toegeken en word dit dus verabsoluteer en vergoddelik. Die 
grens tussen die staat en die ander samelewingsverbande word geïgnoreer en selfs uitgewis en die verskeidenheid vernietig. Die resultaat is voorspelbaar: staatsabsolutisme, onvryheid en tirannie.

Kortliks saamgevat: die individualistiese liberalisme oorskat die individu en onderskat die samelewing, terwyl die kollektivistiese sosialisme presies die omgekeerde doen. Albei bied 'n verminkte beeld van die identiteit van mens en samelewing. Eersgenoemde verabsoluteer die outonomie en eie waarde van die enkeling, terwyl laasgenoemde die outonomie en absolute waarde van die gemeenskap vergoddelik.

\subsection{3 'n Skriftuurlike perspektief}

Albei standpunte is dus 'n ontkenning van die evangelie. Die Skrif leer dat die mens nie outonoom is nie, maar God, wat alleen absolute gesag het, se wil en wet moet gehoorsaam. Die mens en die samelewing se identiteit en betekenis lê dus in gehoorsaamheid aan God.

Sowel kommunaliteit as individualiteit is verder ook blote dimensies van menswees en kan dus nooit die volle mens tipeer nie - selfs nie eers albei saam nie. Omdat individueel en universeel slegs kwaliteite of aspekte van die mens is, is dit meer korrek om te sê dat elke mens ' $n$ individuele kant het as om te sê hy is ' $n$ individu; of, elke mens het 'n sosiale dimensie as om te sê hy is 'n sosiale/ kommunale wese.

Volledige en gesonde menswees veronderstel dus dat sowel die individuele as die kommunale aspekte van menswees (en dit is nie die enigste fasette van menswees nie, vgl. 3.3.1 hieronder) ontwikkel moet word. Nie een van hulle is onbelangrik nie. Die Bybel erken sowel die unieke individualiteit as die sosiale verbondenheid van die mens, ken geen spanning tussen die twee nie en gee ook nie voorkeur aan die een bo die ander nie. God handel in die Skrif met individue en gemeenskappe. Hy eis individuele maar ook gemeenskaplike verantwoording.

Hierdie gedagtes word sistematies uitgewerk in 'n Reformatoriespluralistiese samelewingsfilosofie - die volgende afdeling.

\section{3. 'n Reformatoriese samelewingsfilosofie}

Pluralisme kan baie dinge vir verskillende mense beteken - die Reformatoriese pluralisme is nie die enigste stem op die gebied van hierdie soort samelewingsfilosofieë nie. Weens beperkte ruimte 
word vir die ander pluralistiese stemme verwys na McCarthey et al. (1981:30 e.v.) en Skillen \& McCarthy (1991:3 e.v.). Wat hier volg, is beperk tot 'n puntsgewyse, eenvoudige tipering van die Reformatoriese samelewingsmodel. Dit bestaan uit die volgende drie hoofpunte: die basiese vertrekpunte, die implikasies daarvan vir amp, gesag, mag en verantwoordelikheid in die verskillende samelewingsverbande en derdens 'n verdere verdieping deur middel van 'n modale struktuuranalise van samelewingsverbande.

\subsection{Die basiese vertrekpunte}

Die Reformatoriese samelewingsbeskouing kan in die volgende punte saamgevat word (vgl. Van der Walt, 2000:387-416):

- Dit is nie 'n sintese of 'n kompromie tussen die twee ander modelle (individualisme en kollektivisme) nie, maar bied 'n heeltemal nuwe, 'n derde moontlikheid.

- Dit beklemtoon nie die afsonderlike individue of die kollektiewe gemeenskap nie, maar streef die ideaal na van 'n verskeidenheid (pluraliteit) verbande wat op gelyke vlak langs mekaar staan (nie onder mekaar nie).

- 'n Samelewingsverband word in hierdie visie ook nie bloot as 'n menslike uitvinding en sosiale kontrak gesien nie, maar as 'n moontlikheid wat God self in die skepping gelê het en wat ook aan sy norme onderwerp is.

- Elke samelewingsverband het binne sy eie sfeer 'n eie bevoegdheid en eiesoortige gesag en mag, maar dit is beperkte gesag en mag. God alleen het absolute gesag en mag oor mens en samelewing.

- 'n Reformatoriese of pluralistiese samelewingsbeskouing verwerp dus die hoër-laerskema waarvolgens een verband (bv. die staat of die kerk) 'n hoër status as die ander het en daar gevolglik van byvoorbeeld kerklike skole en universiteite of staatskole en -universiteite sprake kan wees.

- Om dieselfde rede is ook die deel-geheelskema onaanvaarbaar waarvolgens een samelewingsverband die omvattende of oorkoepelende is en die ander verbande slegs onderdele daarvan. In plaas van 'n staatuniversiteit of -skool, verkies 'n Reformatoriese samelewingsfilosofie byvoorbeeld 'n vrye universiteit of skool ook al word dit met staatshulp gefinansier. 
- Om aan te dui hoe 'n Reformatoriese samelewingsbeskouing daar uitsien, kan van die volgende illustrasie gebruik gemaak word: verskillende sirkels wat langs mekaar staan. Die middelpunt van elke sirkel simboliseer die unieke, goddelike norm vir die betrokke verband. Veral gesagsdraers moet weet wat die norm is van die betrokke verband waarbinne hulle met gesag beklee is, sodat hulle die verband en sy lede in die rigting van die vervulling van sy spesifieke taak kan lei. (In die staat is die norm openbare geregtigheid, in die huwelik wedersydse trou, in die kerk gemeenskaplike geloof, ens.) Die feit dat die verbande langs mekaar staan, beteken nie isolasie, fragmentasie of selfs polarisasie nie. Die verskillende verbande moet ook saamwerk. (Daar kan in die diagram tweerigtingpyle tussen al die verskillende sirkels getrek word.) Gebeur dit nie, word die bestaan van die individuele mens, wat in die verskillende verbande lewe, versnipper en hy ervaar spanning tussen botsende lojaliteite.

- 'n Pluralistiese samelewingsmodel is dus gebou op die beginsel van soewereiniteit in eie kring. Soos wat stof, plant, dier en mens elk aan sy eie wette onderworpe is, so ook die menslike samelewingsverbande. Elkeen het 'n eie norm en dus 'n eie gesag en werksterrein. Dit impliseer onder andere die volgende: Negatief gestel mag 'n verband nie sy eie taak verwaarloos nie en ook nie op 'n ander verband se terrein oortree of inmeng nie. Positief gesien, moet dit sy eie roeping as verband vervul en ook help dat die hele samelewing in onderlinge samehang harmonies ontwikkel.

- Indien 'n bepaalde verband sy eie taak en roeping verwaarloos of op die terrein van 'n ander verband oortree, kan hy deur die lede van die verband self of deur ' $n$ ander samelewingsverband tereggewys word. So 'n teregwysing deur 'n ander samelewingsverband is nie 'n skending van die beginsel van soewereiniteit in eie kring nie.

- Die amp, gesag, mag en verantwoording in elke verband is ook eiesoortig. (Dit word by 3.2.2 breër uitgewerk.)

- Ten slotte moet vermeld word dat 'n Reformatoriese samelewingsvisie, behalwe strukturele pluralisme, ook konfessionele pluralisme voorstaan. Behalwe die erkenning van 'n verskeidenheid samelewingsverbande, is die erkenning van 'n verskeidenheid godsdienstige oortuigings belangrik. Die konfessionele verskeidenheid kan strukturele vorm aanneem in byvoorbeeld Chris- 
telike, Joodse, Moslem en sekulêre skole of universiteite. Alle godsdienstige en "sekulêre" groepe moet die reg hê om gelyk behandel te word. Die praktyk bewys dat dit nie help om godsdienstige verskeidenheid te ontken, te onderdruk of as iets "privaats" te beskou nie, want uiteindelik word dit tog maar op allerhande maniere in die "openbare arena" ingesmokkel.

Wat die implikasies van die voorafgaande vir gesagsdraers is, is alreeds gesuggereer maar word nou verder uitgespel.

\subsection{Amp, gesag, mag en verantwoordelikheid}

Ter inleiding moet 'n Reformatoriese visie op gesag duidelik van twee ander gangbare visies onderskei word.

\subsubsection{Die hiërargiese en egalitêre beskouings}

Twee dominante beskouings oor amp, gesag en mag is die hiërargiese en die egalitêre.

Die hiërargiese beskouing gaan gewoonlik met elitisme gepaard: net sekere mense mag in 'n amp staan en gesag uitoefen. Hulle het ook hoër en groter gesag as die "laer" ampte. Hulle het in die praktyk ook 'n geringer - indien enige - verantwoordingsplig na "bo", terwyl die laer ampte aan die hele hiërargiese burokrasie bokant hulle verantwoording moet doen. Dit is duidelik dat hierdie elitistiese, hiërargiese visie maklik tot tirannie, dit wil sê tot 'n verabsolutering van amp, gesag en mag kan lei.

Daarteenoor kan die egalitêre beskouing maklik gebrek aan respek vir amp en gesag tot gevolg hê. In hierdie visie word van die gedagte uitgegaan dat elke persoon oor dieselfde of gelyke gesag beskik. Waar die gevaar in die geval van die eerste gesagsbeskouing diktatuur was, bestaan hier die gevaar van anargie. Dus: in die eerste geval is te veel gesag en in laasgenoemde geval te min gesag.

Myns insiens maak albei hierdie beskouings oor amp en gesag (die hiërargiese en egalitêre) ten spyte van hulle verskille, basies dieselfde fout. Hulle beskou amp en gesag as iets ongedifferensieerd en vra gevolglik die kwantitatiewe vraag, naamlik hoeveel gesag iemand of 'n samelewingsverband toekom, in plaas van die kwalitatiewe vraag, naamlik watter soort gesag by elke amp hoort.

Bowendien bied nie een van hierdie twee visies - ook nie die egalitêre nie - enige prinsipiële waarborg teen totalitarisme nie. In 
eersgenoemde geval domineer die elite en in laasgenoemde geval domineer die massa - dikwels ten spyte van 'n mooi woord soos demokrasie.

\subsubsection{Die Reformatoriese beskouing}

Kortheidshalwe word die Reformatoriese visie op amp, gesag, mag en verantwoordelikheid in twaalf stellings saamgevat. (Vir 'n breedvoeriger verduideliking, vgl. Fowler, 1991:10-16 en 1993:20-32; Schouls, 1972; Van der Walt, 2000:399-404; 2002:282-294 en 2006b.)

- Ampte is nie die eksklusiewe reg van enkelinge, beperk tot sekere posisies van leierskap, status en mag nie. Volgens die Skrif bestaan daar 'n universele roeping tot ampsbekleding, dit wil sê tot diens.

- Daar bestaan ook spesifieke roepings tot 'n verskeidenheid ampte. God roep elke mens, maar nie almal tot dieselfde amp nie.

- Ampte bestaan nie ter wille van oorheersing oor onderhoriges nie, maar om hulle in staat te stel om hulle roeping in die betrokke verband te kan vervul.

- Die spesifieke amp kwalifiseer gesag in elke verband. Dit gaan dus nie oor die vlak of hoeveelheid gesag nie, maar oor die soort of aard van die gesag. Gesag is die reg om 'n amp te mag uitoefen en dit verskil in elke samelewingsverband.

- Amp en gesag is onafskeidelik verbonde, maar moet tog onderskei word. 'n Amp kan nie goed uitgevoer word sonder die nodige gesag (die reg om die amp te beklee) nie. Dit is ook so dat 'n amp beklee kan word as gevolg van vermeende bekwaamheid, blote populalriteit, senioriteit of selfs ' $n$ eiemagtige, onwettige toeëiening van die amp. In so 'n geval het 'n mens egter te make met 'n amp sonder (wettige) gesag.

- Gesag bestaan uit insig en gehoorsaamheid. Gesag is nie dieselfde as mag nie, hoewel mag nodig is om dit uit te voer. Gesag veronderstel insig in die spesifieke taak (volgens die goddelike norm) van die betrokke samelewingsverband, bereidwilligheid om die norm te gehoorsaam en bereidheid om daagliks in insig en gehoorsaamheid te groei.

- 'n Samelewingsverband herken gesag en bevestig iemand in 'n amps- of gesagsposisie. Die persoonlike oortuiging van iemand dat hy in 'n bepaalde samelewingsverband diens kan lewer, be- 
teken nie dat hy outomaties 'n amp sal beklee nie. Die lede van die verband (die betrokke gemeenskap) moet eers sy vermoëns of gawes raaksien, dit erken en hom/haar in die amp verkies, bevestig of aanstel.

- Gesag word dus nie afgelei of oorgedra nie. Bevestiging in 'n gesagsposisie beteken nie die oordra van gesag nie. Die lede van die verband dra nie elk individueel hulle gesag aan die ampsdraer oor, sodat hy namens hulle oor hulle gesag kan uitoefen nie. Dit is 'n tipiese individualistiese, egalitêre gesagsbeskouing. Gesag is kragtens God se skeppingsorde aan elke amp verbind dit hoef nie oorgedra te word nie.

Maar ook die hiërargiese gedagte dat menslike gesag van God (se gesag) afgelei word, is problematies. Gesag word deur God (aan die ampte) gegee en 'n samelewingsverband kan dit alleen erken. Gesag word nie deur God gedelegeer nie, sodat die mens nie namens God sou regeer nie. (God delegeer sy gesag aan niemand nie, behalwe aan Christus.) Die gesag wat ons as mense uitoefen, is kreatuurlike, menslike gesag. Menslike gesag mag nie vergoddelik word nie. Gesagskontrole is dan uitgesluit, omdat kritiek op gesagsuitoefening of weerstand teen magsmisbruik maklik beskou kan word as opstand teen God self.

- In elke samelewingsverband moet tussen gesagsdraers en gesagsonderhoriges onderskei word. 'n Staat bestaan byvoorbeeld uit owerheid en onderdane of regeerders en burgers. Die owerheid is nie die staat nie en ook nie die burgers alleen nie.

- Om gesag (die reg tot 'n amp) te kan uitoefen, is mag (die vermoë) nodig. Die betrokke samelewingsverband magtig of stel die ampsdraer in staat om sy amp en gesag uit te oefen. Dit beteken onder andere dat hulle sy reg om dit te doen erken, ruimte daarvoor skep en die nodige middele daarvoor voorsien. Die mag wat aan 'n bepaalde amp gegee word, mag nie te min wees nie, want dan kan die amp nie effektief behartig word nie. Dit mag egter ook nie te veel wees nie, omdat dit maklik tot magsmisbruik kan lei. Hieruit blyk dit dat, net soos in die geval van gesag, mag ook in elke samelewingsverband eiesoortig en dus beperk is.

- By besluitneming in 'n samelelwingsverband, moet al die lede van die verband betrek word en almal se menings met respek hanteer word. In plaas van 'n meerderheidsbes/uit, moet dus eerder na konsensus gesoek word. Die ampsdraers se taak is nie om te probeer sorg dat ' $n$ bepaalde belangegroep wen nie, maar 
om sáám te besluit oor wat die beste vir die roepingsvervulling van die betrokke verband sal wees.

- Ampsdraers is aan die lede van die betrokke samelewingsverband en aan God verantwoording verskuldig vir die wyse waarop hulle hul ampsgesag uitoefen. Hierdie verantwoordingsplig is noodsaaklik vir deursigtigheid en gesagskontrole.

Hierdie groot verskeidenheid van ampte en soorte gesag, mag en verantwoordelikheid kan nog duideliker deur middel van 'n modale struktuuranalise van die verskillende samelewingsverbande gemaak word.

\section{3 'n Modale struktuuranalise}

$\mathrm{Na}$ Kuyper word die Reformatoriese samelewingsfilosofie deur Vollenhoven en Dooyeweerd verbreed en verdiep. By Kuyper was die beginsel van soewereiniteit in eie kring primêr 'n samelewingsbeginsel (sosiologies van aard) met regionale betekenis (die afbakening tussen verskillende verbande). Dooyeweerd en Vollenhoven (vgl. byvoorbeeld Dooyeweerd, 1957, 1991 en Vollenhoven, 1992: 39-45 en 2005:69-76) het dit verbreed tot 'n kosmologiese beginsel van verskillende wetskringe of modaliteite waarvolgens mens en samelewing funksioneer. (Klapwijk, 1980:557 verduidelik breedvoerig hierdie verskil, nl. 'n verskuiwing van soewereiniteit in eie kring van samelewingsverbande na soewereiniteit in eie kring van wetskringe.) Met behulp van hierdie modaliteiteleer word die Reformatoriese samelewingsfilosofie terselfdertyd verdiep, omdat dit 'n noukeurige struktuuranalise van elke samelewingsverband moontlik maak. Wat so 'n struktuuranalise behels, word hier in eie bewoording in bevatlike taal uiteengesit.

\subsubsection{Die verskillende modaliteite}

Aangesien daar onderlinge verskille bestaan oor die modaliteite wat onderskei word, word alleen die vyftien van Dooyeweerd (vgl. Kalsbeek, 1975:100) hier genoem. Hulle is die volgende: die aritmetiese, ruimtelike, kinematiese, fisiese, biotiese, psigiese, logiese, historiese, linguale, sosiale, ekonomiese, estetiese, juridiese, etiese en pistiese of konfessionele modaliteite.

Hierdie modaliteite is aspekte of fasette van konkrete dinge (stof, plante, diere en mense). In subjektiewe hoedanigheid het stoflike dinge slegs deel aan die eerste vier modaliteite, plante aan die eerste vyf en diere aan die eerste ses, terwyl die mens aan al vyftien 
deel het. Menslike samelewingsverbande funksioneer dus ook in al die modaliteite.

\subsubsection{Funderende en bestemmingsfunksies}

Vollenhoven en Dooyeweerd en hul navolgers toon aan dat, hoewel al vyftien modale aspekte by elke verband voorkom, veral twee modaliteite belangrik is. Hulle word die funderende en die leidende, kwalifiserende of bestemmingsfunksies genoem. By die huwelik en die gesin is die funderende funksie volgens Dooyeweerd die biotiese. Omdat die meeste ander samelewingsverbande in die loop van die geskiedenis as gevolg van die mens se kultuurarbeid ontplooi het, is die historiese by hulle die funderingsfunksie. Die leidende of kwalifiserende funksie is die belangrikste, aangesien dit die unieke aard en taak van elke verband aantoon en dit so van ander onderskei.

\subsubsection{Voorbeelde van 'n struktuuranalise}

Hierdie abstrakte uiteensetting kan meer verstaanbaar gemaak word deur middel van 'n struktuuranalise van twee verbande as voorbeelde.

\section{- Die huisgesin}

As eerste voorbeeld word die gesin gebruik. Die konkrete sake (regterkantste kolom) dien as voorbeelde van hoe al die werklikheidsaspekte (linkerkantste kolom) in die gesin aangetref word:

\begin{tabular}{|c|c|}
\hline $\begin{array}{l}\text { Werklikheidsaspekte } \\
\text { godsdienstige }\end{array}$ & $\begin{array}{l}\text { Konkrete sake } \\
\text { huisgodsdiens }\end{array}$ \\
\hline ETIESE & familietrou \\
\hline juridiese & ouerlike gesag \\
\hline estetiese & tipiese styl van 'n gesin \\
\hline ekonomiese & gesinsbegroting, -finansies \\
\hline sosiale & $\begin{array}{l}\text { onderlinge verkeer, gesinsvermaak, } \\
\text { speletjies, partytjies }\end{array}$ \\
\hline linguale & $\begin{array}{l}\text { gesins(by)name, gesinsidiome of -uitdruk- } \\
\text { kings }\end{array}$ \\
\hline histories-kulturele & gesinsbeplanning, -opvoeding \\
\hline logiese & gesinsopinie, -samesprekings \\
\hline psigiese & gesinsgevoelens, heimwee na huis \\
\hline BIOTIESE & bloedbande \\
\hline
\end{tabular}


fisiese

ruimtelike familietrekke (kinders lyk na hul ouers) woning of ruimte waarbinne gesinslede saamleef

gesin as eenheid

Hoewel die gesin aan al die fasette van die werklikheid deel het, het dit twee oriënteringspunte (in hoofletters hierbo aangedui): die etiese (band van trou) - die kwalifiserende funksie/aspek - en die biotiese (band van bloed) - die funderende faset.

\section{- Die kerk}

As dieselfde struktuuranalise op die kerk toegepas word, lyk dit soos volg:

\section{Werklikheidsaspekte} GELOOF

etiese

juridiese

estetiese

ekonomiese

sosiale

linguale

HISTORIESE

logiese

psigiese

biotiese

fisiese

ruimtelike

getalsmatige

\section{Konkrete sake}

geloofsbelydenis(se)

broedelike/susterlike liefde

kerkorde of kerkreg

die styl van die kerkgebou of styl van 'n erediens

gemeentebegroting/-finansies

gemeenskap van gelowiges

die tipiese kerktaal

kerklike organisasie, mag en opvoeding

die kerklike leer (dogmas) en die wyse waarop kerkmense redeneer

gevoelsmatige of emosionele belewing van verskillende aktiwiteite

die kerk as 'n lewende gemeenskap

allerlei materiële dinge wat die kerk nodig het om te bestaan

'n gemeente se geografiese gebied of die gebou waarin lidmate vergader

lokale kerk en die eenheid met ander kerke van dieselfde belydenis

So 'n struktuuranalise maak dit duidelik dat die kerk histories gefundeerd is, maar deur die geloof gelei en gekwalifiseer word (daarom weer in hoofletters aangedui). Die geloof "kleur" of bepaal ook al die ander modaliteite waaraan 'n kerk as samelewingsverband deel het: Die wyse waarop dit byvoorbeeld sosiaal, ekonomies en juridies 
optree, is heeltemal anders as in die geval van byvoorbeeld ' $n$ staat. (Vir besonderhede vgl. Van der Walt, 2007b:122-124.)

\section{- Wyer toegepas}

Soortgelyke struktuuranalises kan - om slegs enkele voorbeelde te noem - gemaak word van byvoorbeeld 'n klub (sosiaal gekwalifiseerd), 'n bedryf (ekonomies gelei), 'n kunsvereniging (esteties bepaal) en die staat (met 'n juridiese bestemmingsfunksie). Vergelyk verder Dooyeweerd (1986:73) vir sy klassifikasie van die groot verskeidenheid verbande, instellings, organisasies en sosiale verhoudings.

\section{- Groot waarde}

Sowel die abstrak-wetenskaplike as die konkreet-praktiese waarde van sulke analises is voor die hand liggend. Te midde van onduidelikheid en verwarring (vgl. Skillen \& McCarthy, 1991:358, wat aantoon hoe verskillende samelewingsfilosofieë nie daarin slaag om die identiteit, take en regte van verskillende verbande duidelik te maak nie) kan dit help om duidelik te bepaal wat die unieke roeping of taak van 'n spesifieke verband is en hoe dit in 'n konkrete, veelkleurige samelewing gestalte behoort te kry. Dit nog afgesien daarvan dat so 'n analise ook vrugbaar gebruik kan word om die gekompliseerde onderlinge verhoudings ("enkaptiese vervlegting" genoem) tussen die verskillende verbande te ontrafel - 'n aspek wat nie hier verder ondersoek kan word nie.

\section{4. 'n Kritiese evaluering}

Klapwijk (1980:585) merk tereg op dat Kuyper se oproep om 'n "argitektoniese kritiek" van die samelewing duidelike weerklank gevind het by sy navolgers soos Vollenhoven en Dooyeweerd. Hulle het sy gedagtes (soos hierbo verduidelik) tot 'n sisteem, 'n Reformatoriese samelewingsfilosofie uitgebou. $\mathrm{Na}$ hierdie voorlopige afronding het terwyl die behoefte aan 'n Christelike samelewingsfilosofie vandag nypender is as ooit - die respons egter tot 'n groot mate by Kuyper se oproep gebly. Nuwe bydraes op dié gebied vanuit Reformatoriese kring was grotendeels beperk tot herhalings en kleiner korrreksies van onderdele as op 'n ambisieuse verdere sistematiese uitbou daarvan.

\subsection{Kritiek is noodsaaklik}

Nogtans is hierdie kritiese opmerkings om twee redes belangrik. Eerstens bring dit tog nadenke op die gebied 'n tree paar treë ver- 
der. Tweedens herinner dit daaraan dat die Reformatoriese samelewingsfilosofie nie iets staties wil wees en dus ook nie deur ander as 'n starre ideologiese konstruksie beskou moet word nie.

Die punte van kritiek wat hier genoem word, dek nie die hele veld nie, maar raak tog enkele belangrike knelpunte aan. Die probleemgebiede is die volgende: hoe die skeppingsordeninge verstaan moet word; die normatiewe karakter van sosiale differensiasie en (Westerse) vooruitgang; of "soewereiniteit in eie kring" die beste terminologie is; of die bevordering van konfessionele pluralisme nie verdelend in die samelewing werk nie; die bevraagtekening van die noodsaak en waarde van Christelike organisasies en instellings en die vraag of die struktuuranalises van sekere samelewingsverbande klop met die werklikheid.

Agtereenvolgens word kortliks op elkeen van hierdie probleme ingegaan.

\subsection{Die debat oor die skeppingsordeninge}

Calvyn (vgl. Spykman, 1976:195-8) was reeds oortuig dat daar 'n goddelike skeppingsorde bestaan wat normatief vir die mens se hele lewe is. Soos reeds bekend (vgl. Van der Walt, 2008), is hierdie ordeninge volgens Kuyper afgelei van die absolute soewereiniteit van Christus (Matt. 28:18) en God versprei sy gesag oor verskillende samelewingsverbande om gekonsentreerde gesag in die hande van sondige mense te voorkom.

\section{Kritiek op Kuyper}

Hierdie Bybelse gedagte is volgens Klapwijk (1980:534-5) egter te veel vermeng met die onbybelse antiek-Stoïsynse logosleer en die Platonies-Augustiniaanse ideë-realisme. Daarvolgens bestaan die redelike ideë eers in God se gees, terwyl Hy afbeeldinge daarvan (= die skeppingsordeninge) in die menslike rede inskep. Die logiese idees in die skepping is dus denkprodukte van die Goddelike Rede. Tereg stel Klapwijk die vraag of die mens by Kuyper nie te veel net as rasionele wese beskou word nie en die skeppingsorde eensydig as 'n logiese orde gesien word nie.

\section{Dooyeweerd se standpunt}

Ook in Dooyeweerd en Vollenhoven se samelewingsfilosofie speel die skeppingsorde 'n sleutelrol. Daarmee wil hulle tot uitdrukking bring dat, ten spyte van menslike ongehoorsaamheid, die natuur en samelewing onderworpe is en bly aan God se skeppingswil. Hierdie 
oortuiging stel hulle teenoor die heersende historisme van hulle tyd. Hierdie filosofie beskou alles, ook elke samelewingsopset, as histories bepaald en dus veranderlik en relatief. Gevolglik ondermyn die historisme alle vertroue in enige goddelike skeppingsordeninge. Al wat bestaan is tyds- en kultuurgebonde menslike waardes.

Dooyeweerd (1991:292-293) kritiseer ook Barth wat alle klem op die verlossing in Christus lê en uit reaksie teen 'n verkeerde gebruik daarvan nie God se skeppingsopenbaring en -ordeninge wil erken nie. Volgens Dooyeweerd het die sondeval egter nóg die geskape dinge se aard, nóg God se wil vir hulle verander, maar wel die religieuse rigting van die mens se hart. 'n Ontkenning hiervan lei tot die onskriftuurlike standpunt dat die sondeval die struktuur van die skepping sou aangetas het. Dit kan impliseer dat die sonde 'n outonome bestaan naas God verkry - 'n standpunt wat aan Satan te veel mag sou toeken en God van sy allesomvattende soewereiniteit beroof.

\section{Kritiek op Dooyeweerd}

Later moes Dooyeweerd sy leer van die skeppingsordeninge ook teenoor denkers soos Van Peursen verdedig (vgl. Klapwijk, 1980: 566-568). Vir Van Peursen het dit blykbaar nie oor hulle bestaan nie, maar oor die menslike verstaan daarvan gegaan. Volgens hom lê Dooyeweerd 'n te noue band tussen God se verordeninge en die mens se subjektiewe, voorlopige, gebrekkige verstaan van hulle. Ter verdediging van Dooyeweerd moet gestel word dat hy God se skeppingsorde wel as konstant maar nie staties beskou nie. Van die mens se kant gesien, het hy ook beklemtoon dat die mens God se wette vir eie tyd en omstandighede moet positiveer.

'n Medestander soos Klapwijk (vgl. 1995b:209 e.v.) voel egter nog steeds ongemaklik oor die wyse waarop Dooyeweerd die skeppingsorde beskou en wil die Messiaanse of verlossingsboodskap van die Skrif sterker beklemtoon (sy sogenaamde "kreatuurlik-messiaanse" motief). Hy wil dit doen, omdat die kwaad die sin van alles soms op so ' $n$ demoniese wyse aangetas het dat meer nodig is as om net "wet en orde in 'n soewereine kring te ontdek" (Klapwijk, 1995b: 212). Klapwijk (1995b:211) stel dit so: "Ontcijferen moeten we de eindselen, de eschatologische symbolen, ten einde te verstaan de beginselen, de protologische ordeningen. En vice versa." Ook vanuit die toekoms moet dus ontdek word wat God se voornemens met die oorspronklike en tans geskende skepping was. 


\section{Blywende aktualiteit}

In die hedendaagse postmoderne, relativistiese tyd het hierdie debat oor die skeppingsordeninge nog niks aan aktualiteit verloor nie - dit het eerder belangriker geword. Die debat hieroor is nog nie afgehandel nie. Wat wel duidelik geword het, is die volgende. 'n Absolutistiese houding, wat mense se beperkte verstaan van God se skeppingsordeninge oorskat en feitlik daaraan gelykstel, is verkeerd. Maar ook 'n relativistiese instelling, wat beweer dat God se skeppingsorde vir die mens heeltemal onkenbaar is of selfs nie sou bestaan nie, is net so onaanvaarbaar. Die ware toedrag van sake lê heelwaarskynlik tussen die twee uiterstes: Hoewel menslik feilbaar, gaan dit tog oor God se ordeninge wat ontdek moet word. (Die verskil tussen 'n Reformatoriese visie en dié van die postmodernisme op normatiwiteit word breedvoeriger behandel in Van der Walt, 2007d. Vgl. verder die debat in Walsch, et al., 1995.)

\subsection{Sosiale differensiasie en vooruitgang}

Hierdie punt hang nou met die vorige saam. Soos Griffioen (1995: 147) tereg opmerk, heg Dooyeweerd om twee redes groot waarde aan die geleidelike differensiasie in die loop van die geskiedenis van die verskillende verbande. Ten eerste is differensiasie 'n maatstaf om die mate van gehoorsaamheid aan God se skeppingsorde te meet. Ten tweede is dit vir Dooyeweerd 'n teken van modernisering en vooruitgang. Differensiasie self het by hom dus 'n normatiewe betekenis en word nie (omgekeerd) normatief beoordeel nie. Die Westerse kultuur vorm die klimaks van hierdie historiese differensiasieproses.

\section{Kritiek op Kuyper}

Voordat verder oor Dooyeweerd gehandel word, moet opgemerk word dat soortgelyke vrae aan sy voorganger, Kuyper, gestel is. Klapwijk (1980:540 e.v.) toon aan hoe Kuyper se geskiedenisbeskouing deur die Duitse Romantiek en idealistiese filosofie van sy tyd beïnvloed is. As gevolg daarvan glo hy in die vooruitgang van die geskiedenis (kulturele evolusionisme) - met die calvinisme as die hoogtepunt.

Daar tree by Kuyper dus 'n vervaging in tussen "daar staan geskryf" (die Bybel en God se orde) en "dit het geskied" (kulturele ontwikkeling); tussen die normatiewe gesag van God se Woord en die feitlike ontwikkeling van die calvinisme. God se skeppingsordeninge word weerspieël in gewaagde historiese konstruksies. Kuyper neem blykbaar sonder meer aan dat die skeppingsordeninge hulself in die 
- let wel soms twyfelagtige - ontwikkeling van die menslike geskiedenis sal ontsluit.

\section{Kritiek op Dooyeweerd se vooruitgangsidee}

Griffioen (2003:149-179) het ernstige probleme met Dooyeweerd se idee van vooruitgang. Soortgelyke vrae word ook deur Klapwijk (vgl. 1995b) gestel: Bestaan daar wel 'n universele historiese proses van ontsluiting (vooruitgang)? Wat van die baie beskawings wat spoorloos verdwyn het? Kan 'n mens van die normatiewe ontvouing van samelelwingsverbande praat? Is daar nie net soveel voorbeelde van verval of agteruitgang nie? Volgens Klapwijk (1995b:219) word Dooyeweerd se opvatting oor die geskiedenis heel waarskynlik meer bepaal deur die Duitse idealistiese filosofie van sy tyd as deur die Skrif. Dit ruik bowendien sterk na Eurosentrisme. (Klapwijk self wil eerder die kulturele konteks as vertrekpunt neem en homself deur 'n kreatuurlik-messiaanse perspektief laat lei - vergelyk hierbo onder 4.2). Ten spyte van Dooyeweerd se kritiek op die historisme (vgl. weer 4.2 hierbo) wil dit lyk asof hy ook in dieselfde slagyster getrap het.

\section{Primitief en modern bevraagteken}

Vrieze (1977:167-204) het reeds vroeër soortgelyke kritiek gehad. Volgens Dooyeweerd se ontsluitingsideaal moet vroeëre samelewings as "primitief" beskou word, omdat hulle nog ongedifferensieerd was, terwyl die huidige samelewings (veral die Westerse) as "modern" getipeer word. (Differensiasie is die norm.)

Reeds oppervlakkig beskou, klink dit effens arrogant. Nog belangriker is die vraag na wat dan die kriterium is om kulture en hulle samelewings te evalueer - dit kan tog nie aan 'n/die samelewing(s) selfs ontleen word nie.

Volgens Vrieze verreken Dooyeweerd nie die religieuse karakter van samelewings en hulle verbande voldoende nie. Hy stem wel saam dat die sogenaamde primitiewe samelewings onontslote en staties was. Dit is egter nie die belangrikste faktor nie, maar wel hulle religieuse rigting. Omdat daar in so 'n samelewing nie tussen verskillende verbande onderskei word nie en alles in 'n ongedifferensieerde geheel opgaan, noem Vrieze (1977:177) dit 'n religieus totalitêrgerigte pseudo-samelewing. Dit is egter nie net "primitiewe" volkere by wie 'n omvattende samelewingsorde vergoddelik word nie. Volgens Vrieze (1977:201, 202) kwalifiseer die hedendaagse Amerkaanse samelewing ook as "primitief", aangesien die tegniesekonomiese al die verskillende ander verbande in die VSA oorheers. 


\section{4 "Soewereiniteit" bevraagteken}

Ook hierdie kritiekpunt hang tot 'n mate saam met dié een oor die skeppingsordeninge (4.2 hierbo). Die kritiek gaan nie oor die inhoud van die beginsel nie (vgl. byvoorbeeld Spykman, 1976 se uitstekende historiese en sistematiese uiteensetting daarvan), maar oor die benaming. Vollenhoven (1992:44 en 2005:72) sê byvoorbeeld alreeds dat sy voorganger, Kuyper, nie duidelik genoeg tussen die soewereiniteit van God en soewereiniteit in die beginsel van soewereiniteit in eie kring onderskei het nie. Vollenhoven is blykbaar van mening dat die woord soewereiniteit alleen op God en nie op menslike verbande van toepassing is nie. Soewereiniteit dui vir hom te veel op die onbybelse gedagte van menslike outonomie (d.w.s dat die mens sy eie wetgewer sou wees; vgl. ook Spykman, 1976:166). Dit mag ook die rede wees waarom latere Reformatoriese denkers die bekende uitdrukking liewer laat verval het. Klapwijk (1995b:210) praat byvoorbeeld liewer van die "eie verantwoordelikheid en bevoegdheid" van die verskillende samelewingsverbande. Wolters (1992:83) suggureer "gedifferensieerde verantwoordelikheid" en Spykman (1976:166) noem alreeds veel vroeër sphere-authority, sphere-responsibility, sphere-stewardship as alternatiewe benamings.

Kok (19967:227-228) bied verdere terminologiese opheldering in hierdie verband. Hy maak eerstens 'n onderskeid tussen soewereiniteit en (relatiewe) outonomie. Eersgenoemde het met modale en laasgenoemde met individuele verskille te make. State het byvoorbeeld dieselfde (juridies gekwalifiseerde) soewereiniteit. Maar in hulle individuele verhouding tot mekaar is hulle nie soewerein nie, maar (relatief) outonoom.

In die tweede plek beklemtoon Kok (1996:228; vgl. ook Vollenhoven hierbo) dat "outonome" nie verstaan moet word in die gangbare sekulêre betekenis van menslike selfgenoegsaamheid teenoor God (die mens as sy eie wetgewer), nie. Derdens beteken die outonomie van 'n samelewingsverband ook nie dieselfde as outargie, dit wil sê dat 'n verband volkome selfgenoemsaam is nie.

\subsection{Konfessionele pluralisme verder uitgewerk}

Heelwaarskynlik as gevolg van die tyd waarin Dooyeweerd geleef het (destyds was die hedendaagse konflik tussen verskillende godsdienste en kulture nog nie so 'n brandend-aktuele vraagstuk in sy land en Europa nie) het hy nog nie soveel klem op konfessionele pluralisme gelê en dit breër, dieper en konkreter uitgewerk nie. 


\section{Vooruitgang na Dooyeweerd}

Sy geesgenote ná hom het dit egter wel gedoen (vgl. bv. McCarthy et al., 1981:38-40). Hulle beskou die beginsel van konfessionele pluralisme ook nie as iets wat verdelend in die samelewing werk nie, maar juis as noodsaaklik om reg aan alle godsdienstige groepe te laat geskied.

Ook op hierdie punt was daar dus vooruitgang. Vollenhoven en Dooyeweerd het in hulle samelewingsfilosofie slegs tussen twee soorte pluralismes onderskei, naamlik tussen die strukturele verskeidenheid en die religieuse rigting van die samelewingsverbande. Mouw en Griffioen (1991:1-19) voeg 'n derde, belangrike element hierby, naamlik die kontekstuele. Hulle onderskei die volgende (Mouw \& Griffioen, 1991:17, 18): "directional (religious) pluralism, associational (structural) pluralism, contextual (cultural) pluralism". In die res van hulle boek toon die twee skrywers aan hoe hierdie drie soorte verskeidenheid in die samelewing onafskeidelik aan mekaar verbonde is en mekaar wedersyds beïnvloed. In hulle samelewingsbeskouing wil hulle dus doelbewus ook aan kulturele verskille aandag gee. Dit is 'n belangrike korreksie op Dooyeweerd wat (vgl. 4.3) nog taamlik Eurosentries gedink het.

\subsection{Christelike organisasies en instellings}

Omdat die Reformatories-sosiale denkers van oortuiging was dat konfessionele diversiteit ook strukturele gestalte in die openbare lewe mag aanneem, is talle Christelike organisasies en instellings in veral Nederland maar ook elders in die wêreld tot stand gebring. Klapwijk (1995d) beskryf die verkeerde en regte motiewe daarager asook die verskillende soorte organisasies. Klapwijk (1995c) verduidelik ook waarom parakerklike organisasies nie die beste oplossing vir Christene se betrokkenheid in die samelewing is nie.

\section{Wending}

Gedurende die tweede helfte van die vorige eeu moes hierdie Christelike organisasies/instellings egter skerp kritiek in veral Nederland verduur. Sulke Christelike politieke partye, vakbonde, skole en radiostasies sou "verzuiling" (pillarisation) bevorder, met ander woorde verdelend in die samelewing werk. 


\section{'n Belangrike bydrae tot die siviele samelewing en teen sekularisme}

Sedertdien het hierdie reaksie egter by sommige Christene weer vir nuwe waardering plek gemaak (vgl. byvoorbeeld Buijs et al., 2003). Die herwaardering hang saam met die insig dat sulke konfessionele organisasies 'n belangrike deel kan uitmaak van die opbou van die burgerlike samelewing (civil society) in baie lande (vgl. Blokhuis \& Hielema, 2006). Van der Walt (2007c) is verder van mening dat Christelike organisasies 'n effektiewe manier kan wees om die groeiende sekularisme in die samelewing teë te werk. Teenoor ander wyses van samelewingsverandering behoort hierdie manier veel meer aandag, ook in Suid-Afrika, te ontvang.

\subsection{Struktuuranalises bevraagteken}

'n Laaste voorbeeld van voortgaande besinning in reformatoriese kring stel die vraag of die struktuuranalise van sekere samelewingsverbande korrek is. Vrieze (1977:161 e.v.) verskil byvoorbeeld van Dooyeweerd se analise van die huwelik en die gesin.

\section{Die huwelik anders geanaliseer}

Volgens Vrieze is die huwelik nie bioties-seksueel gefundeerd soos Dooyeweerd beweer nie. Die verband bestaan nie in die eerste plek uit 'n biotiese gebeure nie, maar 'n vormingsdaad. Verder misken so 'n biotiese fundering die mens se bestaanswyse as man en vrou. Hy (Vrieze, 1977:163) verduidelik dit soos volg: Agter die herleiding van die huwelik tot 'n biotiese bestaanswyse, lê die reduksie van die geslagtelike verskille tot slegs ' $n$ verskil in biotiese funksionering. Dit impliseer ' $n$ verwarring van individualiteit en modaliteit. Die man en die vrou fungeer in die biotiese bestaanswyse, omdat hy man of sy vrou is. Die bepaalde wyse van funksionering veroorsaak egter nie die man- of vrouwees nie, maar dit volg daaruit. Die geslagtelike verskil kan nie modaal (bioties) gedui word nie, omdat dit premodaal van aard is. Omdat die huwelik op 'n fundamentele geslagtelike verskil binne die mensheid (man- en vrouwees) gegrond is, kan dit nie deur middel van 'n funderings- en bestemmingsfunksie (d.w.s. modaal) gekarakteriseer word nie.

\section{Die gesin ook anders bekyk}

Vrieze verskil ook van Dooyeweerd se tipering van die gesin as 'n "natuurlike" gemeenskap, omdat gesinne volgens hom gevorm en in stand gehou moet word. Volgens Vrieze $(1977: 166,167)$ is die gesin 'n oriënterings- en verankeringsgemeenskap waarin jong mense 
moet leer om op God se verskillende roepings te antwoord, dit wil sê hulle moet leer om lewenskoers te vind.

Hierdie twee voorbeelde herinner daaraan dat die Reformatoriese struktuuranalises van verskillende verbande, hoe waardevol ook al, nie gekanoniseer mag word nie. Die vraag moet steeds wees of dit klop met die werklikheid. Verder behoort die kontekstuele (of kulturele) element (vgl. Mouw en Griffioen, 1991 hierbo) 'n inherente deel van sulke struktuuranalises te wees, omdat samelewingsverbande nie in 'n lugleegte nie, maar binne 'n bepaalde kultuur ontstaan en bestaan.

Hiermee is die einde van 'n baie kort en onvolledige kritiese evaluering bereik. Dit moet onthou word dat, ten spyte van korreksies en die noodsaak van verdere besinning, dit die Reformatoriese samelewingsfilosofie se besondere waarde as geheel nie verminder nie. Dit nut daarvan blyk ook uit sy toepasbaarheid op verskillende terreine - die slotgedeelte van hierdie ondersoek.

\section{Praktiese toepasbaarheid}

'n Mens sou die praktiese toepasbaarheid as die toets vir hierdie samelewingsfilosofie kon noem. 'n Samelewingsvisie is immers waardeloos as dit nie ook 'n bydrae tot samelewingsverandering kan maak nie. Wolters (1992:74 e.v.) en Van der Walt (2002:295-335) bespreek byvoorbeeld verskillende moontlike maniere van samelewingsverandering, motiveer waarom hulle vir die Reformatoriese model kies en toon aan hoe die samelewing volgens hierdie model vernuwe kan word.

Strukturele en konfessionele pluralisme word, soos reeds betoog, nie in die Reformatoriese samelewingsfilosofie geskei nie. Die twee word egter hierna onderskei om die waarde van elkeen vir die huidige samelewing te kan bepaal. Ten slotte volg iets oor samelewingsverandering.

\subsection{Die waarde van strukturele pluralisme}

Die besondere waarde van strukturele pluralisme is gebou op 'n modale analise van die verskillende samelewingsverbande. Dit maak 'n mens se oë vir allerlei soorte "ismes" oop. 'n Isme dui op die verabsolutering van een aspek van die werklikheid of een verband in die samelewing ten koste van al die ander. Behalwe individualisme en kollektivisme (reeds bespreek) is materialisme, biologisme, ekonomisme en historisme voorbeelde hiervan. 


\subsubsection{Die gevaar van ismes}

Enige isme is ' $n$ poging om alles tot een faset/verband te reduseer. So ' $n$ herleiding beteken 'n ernstige distorsie van die werklikheid. Op samelewingsterrein lei dit tot totalitaristiese ideologieë. Die Reformatoriese samelewingsfilosofie is dus ' $n$ middel om sulke ideologieë raak te sien en die verwrongenheid wat hulle veroorsaak prakties te probeer teëwerk. 'n Goeie voorbeeld daarvan is Goudzwaard (1984).

\subsubsection{Voorbeelde}

Hier volg enkele voorbeelde hoe Reformatoriese denkers die voorafgaande toegepas het.

- Politieke oorheersing word byvoorbeeld deur Zylstra (1968) en Runner (1974) bestry.

- Verwetenskapliking en vertegnisering van die samelewing Vanuit 'n pluralistiese samelewingsvisie beskryf Van Riessen (1970:68 e.v.) hoe wetenskap en tegniek die samelewing van die toekoms gaan oorheers. Ten tye van Schuurman (1980) het die kontoere en gevare van so 'n samelewing al duideliker geword en in sy jongste geskrif (Schuurman, 2005) word sy waarskuwings nog dringender en indringender.

\section{- Verkommersialisering}

Hierdie vertegnisering gaan tans hand aan hand met die neokapitalistiese ekonomisme of verkommersialisering van die hele samelewing. Ook samelewingsverbande soos die gesin, kerk en universiteit, wat nie ekonomies gekwalifiseerd is nie, word as ekonomiese aangeleenthede beskou en so behandel. Reeds 30 jaar gelede het Goudzwaard (1979) op indringende wyse hierdie kapitalistiese ideologie - kritiekloos ook deur baie Christene aanvaar - ontleed en daarteen gewaarsku. Destyds waarsku ook Vrieze (1977) dat vooruitgang nie net in tegnies-ekonomiese sin verstaan en gemeet mag word nie. Dit lei volgens hom (Vrieze, 1997:202) tot 'n samelewing wat nie minder totalitêr is as in die geval van 'n politieke tirannie nie: die gesin, onderwys, wetenskap, kuns, ontspanning en selfs politiek word as blote onderdele van die ekonomiese gesien en hulle waarde alleen volgens materiële maatstawwe (van veral produksie en verbruik) gemeet. Onlangs wys Simons (2007) op die nadelige gevolge van hierdie toenemende tegnisme en ekonomisme vir landbou wêreldwyd. 


\section{- Globalisering}

Die neo-kapitalistiese ideologie is vandag 'n globale fenomeen. Multi-nasionale sakeondernemings en finansiële markte is so sterk en invloedryk, dat hulle die soewereiniteit van 'n arm land kan bedreig en sy ekonomie in duie kan laat stort. Wêreldmarkte domineer nasionale regerings en al die ander lewensterreine soos die gesinslewe, onderwys, wetenskap en selfs godsdiens. Son (1999:187) merk tereg op dat dit vandag nie genoeg is om vir sosiale pluralisme binne ' $n$ bepaalde land te stry as die internasionale ekonomiese reuse nie aangepak word nie. Volgens hom is daar geen rede waarom die ou beginsel van soewereiniteit in eie kring nie vandag ook op globale terrein toegepas kan word nie. Hy noem voorbeelde van nie-regeringsorganisasies (NRO'S) wat ernstige wêreldomvattende probleme al suksesvol hanteer het. Sy vraag is waarom Christelike organisasies nie ook op dieselfde wyse internasionaal vir 'n verskeidenheid doeleindes kan saamwerk nie.

\section{- Groepsregte}

In die debat oor menseregte gaan dit (as gevolg van die invloed van 'n individualistiese samelewingsvisie) dikwels net oor individuele regte. Die Reformatoriese samelewingsfilosofie erken egter ook (vgl. Zylstra, 1991) die regte van groepe en samelewingsverbande en kan dus help om die gesprek oor menseregte, ook in Suid-Afrika, te help verbreed. Na aanleiding van Mouw en Griffioen (1993) se breë onderskeid (reeds hierbo genoem), sou 'n mens ten minste institusionele, godsdienstige en kulturele regte moet onderskei.

- Versterking van die siviele (burgerlike) samelewing

Die begrip civil society word op uiteenlopende maniere gedefinieer (vgl. Blokhuis \& Hielema, 2006). Een van die mees algemene definisies is egter dat dit die samelewingsruimte tussen die meer persoonlike lewe (van bv. huwelik en gesin) en die meer openbare (bv. politiek en ekonomie) is. Hierdie "middelterrein" bestaan uit talle instellings en organisasies wat deur die burgery tot stand gebring is vir 'n verskeidenheid oogmerke. Die burgerlike samelewings is as 't ware die sosiale sement wat 'n samelewing saambind. Daar is egter baie lande waar 'n civil society nie ontwikkel het nie of gewelddadig onderdruk is. Omdat ' $n$ Reformatoriese samelewingsfilosofie die totstandkoming van sulke burgerlike organisasies prinsipieel regverdig en prakties steun, kan dit hier 'n belangrike bydrae lewer. Son (1999:184 e.v.) toon byvoorbeeld aan hoe NRO's in Korea kragtige teenvoeters teen staatsabsolutisme was. In sy opstel sien Buijs (2006:19-41) ook 
groot moontlikhede vir die betrokkenheid van spesifiek Christelike siviele organisasies/instellings in hedendaagse samelewings.

\section{- Armoede en ander sosiale vraagstukke}

Ten slotte moet genoem word dat daar feitlik nie 'n sosiale vraagstuk bestaan wat nie 'n strukturele analise van die samelewing nodig maak nie. Kuyper (1991) toon reeds in 1891 aan dat armoede nie met oppervlakkige remediëring (bv. noodhulp) opgelos kan word nie. Dit is 'n strukturele probleem. Armoede, nes rykdom, is in die strukture van die samelewing "ingebou". Daarom kan dit alleen deur verandering in die samelewingstrukture opgelos word. Van der Walt (2006a en 2007a) pleit ook dat die kerke se simptoomdiakonieë met meer radikale vorme van diakonieë (wat ook die strukture analiseer en hanteer) vervang moet word.

Behalwe strukturele pluralisme, is ook konfessionele pluralisme van groot waarde in die kontemporêre samelewing - 'n tweede bate.

\subsection{Die waarde van konfessionele pluralisme}

Een van die groot vraagstukke van die wêreld vandag is dat daar feitlik nêrens meer 'n religieus-homogene samelewing bestaan nie die meeste het multireligieus geword, hulle moet 'n verskeidenheid godsdienstige oortuigings akkommodeer.

\section{Die skynoplossing van privaat-publiek}

Regerings met sekulêre konstitusies (sommige meer godsdienstig neutraal en andere openlik antigodsdienstig) probeer die probleem van botsings tussen verskillende godsdienstige groepe oplos deur middel van 'n onderskeid tussen privaat en openbaar. Godsdienstige oortuigings word as iets persoonliks of privaat gereken en mag nie in die openbare sfeer van onderwys, ekonomie, politiek, ensovoorts 'n rol speel nie - dit benadeel (veral politieke) eenheid.

So 'n skeiding is egter nie alleen kunsmatig nie (waar presies hou die private terrein op en begin die openbare?), maar ook nie eerlik, regverdig of prakties nie. Dit is nie eerlik nie, want al die ander godsdienste word uit die openbare lewe verban, sodat die plek deur die religie van die sekularisme ingeneem kan word. Dit is nie regverdig nie, omdat sekulariste wel in die openbaar hulle geloof mag uitleef, maar dié reg nie aan ander godsdienste gegun word nie. Ten slotte is dit ook nie prakties nie, want - soos reeds aangetoon - kan samelewingstrukture nooit van hule religieuse rigting losgemaak word nie. Die gevolg is dat die godsdienstige verskille nooit werklik 
onderdruk kan word nie en mense op allerlei - selfs onaanvaarbare - wyses tog probeer om hulle diepste oortuigings te laat geld.

\section{Die Reformatoriese oplossing}

Reformatoriese konfessionele pluralisme, wat strukturele vorm in religieus-georiënteerde skole, politieke partye, vakbonde, ensovoorts aanneem, deurbreek prinsipieel en prakties die gangbare privaat-openbare dualisme. In plaas van 'n ontkenning en onderdrukking van godsdienstige verskille, wil dit die konfessionele verskeidenheid erken en ook struktureel ruimte vir die vrye uitlewing daarvan skep. Indien dit nie gebeur nie, mag godsdienstige groepe selfs geweld gebruik om erken te word. Aangesien die reg om aan 'n mens se religieus oortuigings in die openbaar uiting te gee, nie tot ' $n$ sekere groep (bv. Christene) beperk is nie, beantwoord die Reformatoriese oplossing ook aan die sentrale politieke norm van onpartydige geregtigheid.

\subsection{Samelewingsverandering}

Aan die begin van hierdie afdeling is gestel dat 'n samelewingsvisie wat sy sout werd is ook tot samelewingsverandering behoort te lei. Hoe presies dit gedoen kan word, het nou duideliker geword. Terwyl baie Christene invloed op die samelewing wil uitoefen deur persoonlike getuienis en dade of deur hulle kerke, bied die Reformatoriese samelewingsfilosofie 'n derde, kragtiger middel in Christelike organisasies en instellings. Weens ruimtegebrek kan hier nie verder op die probleme rondom en die waarde van sulke organisasies/instellings ingegaan word nie. (Vir besonderhede vgl. Buijs et al., 2003, Klapwijk, 1995d en Van der Walt, 2002:325-335 en 2007c). Hier kan alleen gekonstateer word dat daar in georganiseerde, gestruktureerde Christelike aksies groot potensiaal tot samelewingsverbetering lê. Hierdie moontlikheid is nog nie naastenby in SuidAfrika (en ook in ander wêrelddele) ontgin nie.

\section{Samevattende terugskouing}

'n Lang pad is afgelê. Dit het begin met die aktuele probleem waarom so min Christene vandag werklik in die samelewing betrokke is. 'n Gedeeltelike antwoord op die vraag was dat hulle nie oor 'n integrale Christelike samelewingsbeskouing beskik nie. Die Reformatoriese samelewingsfilosofie is as moontlike kandidaat geïdentifiseer om dié leemte te vul. Om te kwalifiseer is dit egter eers Skriftuurlik en histories getoets (vgl. Van der Walt, 2008). Verder is dit (in hierdie, tweede artikel) nie net sistematies uiteengesit nie, 
maar ook krities geëvalueer. Uiteindelik is aangetoon dat dit nie abstrakte studeerkamerfilosofie is nie, maar prakties toegepas kan word. Op die vraag waarmee die ondersoek begin het, is dus aan die einde 'n antwoord gegee - al bly dit hoe voorlopig.

In 'n beeld gestel het Christene nie net klere vir die huis en die kerk benodig nie. Hulle het ook ander klere nodig om met vrymoedigheid in die sogenaamde openbare lewe te kan verskyn. Hopenlik bied 'n Reformatoriese samelewingsfilosofie vir Christene die nodige "kleding" om met oortuiging, entoesiasme en diensbaarheid in die samelewing buite die beperkte kring van hul persoonlike en kerklike lewe betrokke te raak.

\section{Geraadpleegde bronne}

BLOKHUIS, P. \& HIELEMA, E.K., eds. 2006. Civil society: East and West. Sioux Center: Dordt College.

BUIJS, G.J. 2006. The promises of civil society. (In Blokhuis, P. \& Hielema, E.K., eds. Civil society: East and West. Sioux Center: Dordt College. p. 1942.)

BUIJS, G.J., et al. 2003. Wat je zegt, ben jezelf: identiteit en Christelijke organisaties. Zoetemeer: Boekencentrum.

DOOYEWEERD, H. 1957. A new critique of theoretical thought. Vol. 3. Amsterdam: Presbyterian \& Reformed Publishing.

DOOYEWEERD, H. 1986. A Christian theory of social institutions. La Jolla: Herman Dooyeweerd Foundation.

DOOYEWEERD, H. 1991. Roots of Western culture. (In Skillen, J. \& McCarthy, R.M. Political order and the plural structure of society. Atlanta: Scholars Press. p. 262-296.)

FOWLER, S. 1991. A Christian voice among students and scholars. Potchefstroom: Institute for Reformational Studies.

FOWLER, S. 1993. Communities, organisations and people. Pro rege, 11(4):2032.

GOUDZWAARD, B. 1979. Capitalism and progress: a diagnosis of Western society. Toronto: Wedge.

GOUDZWAARD, B. 1984. Idols of our time. Sioux Center: Dordt College.

GRIFFIOEN, S. 1995. The relevance of Dooyeweerd's theory of social institutions. (In Griffioen, S. \& Balk, B.M., eds. Christian philosophy at the close of the twentieth century: assessment and perspective. Kampen: Kok. p. 139-158.)

GRIFFIOEN, S. 2003. Moed tot cultuur: een actuele filosofie. Amsterdam: Buijten \& Schipperheijn.

HIEMSTRA, J.L. 1997. Worldviews on the air: the struggle to create a pluralist broadcasting system in the Netherlands. Lanham: University Press of America.

KALSBEEK, L. 1975. Contours of a Christian philosophy: an introduction to Herman Dooyeweerd's thought. Toronto: Wedge. 
KLAPWIJK, J. 1980. Honderd jaar filosofie aan de Vrije Universiteit. (In Van Os, M. \& Wieringa, W.J., reds. Wetenschap en rekenschap 1880-1980: een eeuw wetenschapsbeoefening en wetenschapsbeschouwing aan de Vrije Universiteit. Kampen: Kok. p. 529-593.)

KLAPWIJK, J. 1995a. Op zoek naar de mensbeeld van liberalisme, socialisme en Christen-democratie. (In Van Woudenberg, R. \& Griffioen, S., reds. Jacob Klapwijk: transformationele filosofie, cultuur-politieke ideeën en de kracht van een inspiratie. Kampen: Kok. p. 134-151.)

KLAPWIJK, J. 1995b. Transformationele analyses: over soevereiniteit in eigen kring, dieptehermeneutiek en filosofie in loco. (In Van Woudenberg, R. \& Griffioen, S., reds. Jakob Klapwijk: transformationele filosofie, cultuurpolitieke ideeën en de kracht van een inspiratie. Kampen: Kok. p. 209220.)

KLAPWIJK, J. 1995c. Abraham Kuyper en de kerk in de wereld: parakerkelijke of extramurale presentie? (In Van Woudenberg, R. \& Griffioen, S., reds. Jacob Klapwijk: transformationele filosofie: cultuur-politieke ideeën en de kracht van een inspiratie. Kampen: Kok. p. 152-162.)

KLAPWIJK, J. 1995d. Christelijke organisaties in verlegenheid. (In Van Woudenberg, R. \& Griffioen, S. Jacob Klapwijk: transformationele filosofie. Kampen: Kok. p. 91-123.)

KOK, J.H. 1996. Patterns of the Western mind: a reformed Christian perspective. Potchefstroom: Institute for Reformational Studies.

KUYPER, A. 1991. The problem of poverty: a translation of the opening address at the First Christian Social Congress in the Netherlands, November 9, 1891. Edited and introduced by J.W. Skillen. Grand Rapids: Baker.

MARSHALL, P. 1994. Liberalism, pluralism and Christianity. (In Chaplin, J. \& Marshall, P., eds. Political theory and Christian vision: essays in memory of Bernard Zylstra. Lanham: University Press of America. p. 143-162.)

MCCARTHY, R., OPPEWAL, D., PETERSEN, W., SPYKMAN, G., eds. 1981. Society, state and schools: a case for structural and confessional pluralism. Grand Rapids: Eerdmans.

MOUW, R. \& GRIFFIOEN, S. 1993. Pluralisms and horizons: an essay on Christian public philosophy. Grand Rapids: Eerdmans.

RUNNER, H.E. 1974. Scriptural religion and political task. Toronto: Wedge.

SCHOULS, P. 1972. Insight, authority and power. Toronto: Wedge.

SCHUURMAN, E. 1980. Technology and the future: a philosophical challenge. Toronto: Wedge.

SCHUURMAN, E. 2005. The technological world picture and an ethics of responsibility. Sioux Center: Dordt College.

SIMONS, P. 2007. Tilling the good earth: the impact of technicism and economism on agriculture. Potchefstroom: North-West University. (D.Phil. dissertation.)

SKILLEN, J.W. \& MCCARTHY, R.M., eds. 1991. Political order and the plural structure of society. Atlanta: Scholars Press.

SON, B.H. 1999. Relevance of sphere sovereignty to Korean society. (In Van der Kooi, C. \& De Bruijn, J., eds. Kuyper reconsidered: aspects of his life and work. Amsterdam: V.U. p. 179-189.)

SPYKMAN, G.J. 1976. Sphere-sovereignity in Calvin and the Calvinist tradition. (In Holwerda, D.E., ed. Exploring the heritage of John Calvin. Grand Rapids: Barker. p. 163-208.) 
SPYKMAN, G.J., COOK, G., DODSON, M., GRAHN, L., ROOY, S. \& STAM, J. 1988. Let my people live: faith and struggle in Central America. Grand Rapids: Eerdmans.

VAN DER WALT, B.J. 2000. Visie op die werklikheid: die bevrydende krag van 'n Christelike lewensbeskouing en filosofie. Potchefstroom: Instituut vir Reformatoriese Studie.

VAN DER WALT, B.J. 2002. The liberating message: a Christian worldview for Africa. Potchefstroom: The Institute for Contemporary Christianity in Africa.

VAN DER WALT, B.J. 2006a. 'n Besinning oor die verruiming van die diakenamp: simptoom- of radikale diakonie? Deel 1. Die Kerkblad, 109(3194):28-29.

VAN DER WALT, B.J. 2006b. Leadership models in Africa, the West and the Bible. (In Van der Walt, B.J. When African and Western cultures meet. Potchefstroom: The Institute for Contemporary Christianity in Africa. p. 123-156.)

VAN DER WALT, B.J. 2007a. 'n Besinning oor die verruiming van die diakenamp: drie soorte radikale diakonieë. Deel 2. Die Kerkblad, 109(3195):14-16.

VAN DER WALT, B.J. 2007b. Church and society. (In Van der Walt, B.J. Transforming power. Potchefstroom: The Institute for Contemporary Christianity. p. 105-148.)

VAN DER WALT, B.J. 2007c. Identity and relevance: the urgent need for Christian organisations and institutions in an increasing secular world. (In Van der Walt, B.J. Transforming power. Potchefstroom: The Institute for Contemporary Christianity. p. 297-318.)

VAN DER WALT, B.J. 2007d. Die historiese agtergrond van die postmoderne visie op normatiwiteit en op die Christelike lewensvisie. Koers, 72(4):549581.

VAN DER WALT, B.J. 2008. Onderweg na 'n Christelike samelewingsfilosofie: Bybelse grondslae en historiese ontwikkeling. In die Skriflig, 42(1):1-23.

VAN RIESSEN, H. 1970. The society of the future. Philadelphia: Presbyterian \& Reformed Publishing.

VOLLENHOVEN, D.H. Th. 1992 [1950]. De soevereiniteit in eigen kring by Kuyper en ons. (In Tol, A. \& Bril, K.A., reds. Vollenhoven als wijsgeer: inleidingen en teksten. Amsterdam: Buijten \& Schipperheijn. p. 36-46.)

VOLLENHOVEN, D.H. Th. 2005 [1945]. Introduction to philosophy. Ed. by J.H. Kok \& A. Tol. Sioux Center: Dordt College.

VRIEZE, M. 1977. Nadenken over de samenleving: gedachten over de wetenschappelijke bestudering van omgang en samenleving. Amsterdam: Buijten \& Schipperheijn.

WALSH, B.J., HART, H. \& VANDERVENNEN, R. 1995. The ethos of compassion and the integrity of creation. Lanham: University Press of America.

WOLTERS, A.M. 1992. Die skepping herwin: Bybelse grondslae van 'n Reformatoriese lewensbeskouing. Potchefstroom: Instituut vir Reformatoriese Studie.

ZYLSTRA, B. 1968. From pluralism to collectivism: Harold Laski's political theory. Assen: Van Gorcum.

ZYLSTRA, B. 1991. The United States Constitution and the rights of religion. (In Skillen, J. \& McCarthy, R.M. Political order and the plural structure of society. Atlanta: Scholars Press. p. 315-332.) 


\section{Kernbegrippe:}

differensiasie (sosiale)

reformatoriese tradisie

samelewingsfilosofie

sosiale gesag/mag

struktuuranalise

\section{Key concepts}

differentiation (social) reformational tradition social authority/power social philosophy structural analysis 
